\title{
Research and friendship: John Mathew and his Aboriginal informants
}

\author{
Malcolm D. Prentis
}

Between 1879 and 1928, John Mathew (1849-1929) published two books and over 20 articles on aspects of Aboriginal culture, society and languages. In that period he gradually developed some repute as an ethnographer, linguist and student of Aboriginal society. He has generally been included in subsequent lists of pioneers of Aboriginal ethnography in the period from the 1880 s to the 1920 s. This was the transitional phase between the 'mere collectors' like R. Brough Smyth and E.M. Curr and the organised, systematic, academically-based professional researchers from the 1920 s onwards. Histories of Australian anthropology which list the pioneers of the discipline still usually give the names A.W. Howitt, Lorimer Fison, W.E. Roth, W.Baldwin Spencer and FJ.Gillen, R.H. Mathews and John Mathew. ${ }^{1}$ These men foreshadowed the professionalisation of the discipline. Some, such as Spencer and Mathew, actively promoted it. As largely spare-time and self-trained in the field, their work was necessarily less systematic than that of their full-time professional successors. Theories 'shaped their field studies' and they 'took a critical and constructive part in [the] formulation' of theory. They were motivated by a number of factors: the 'before it's too late' notion of preservation, curiosity, specific interest in confirming theories or ideologies about human nature and evolution. ${ }^{2}$ The reputation of Spencer and Gillen has survived better than the others, for scholarly as well as political reasons. John Mathew shared many of these characteristics. But in certain respects, he was significantly different.

John Mathew was born at Aberdeen, Scotland in 1849. Following his father's death and mother's emigration and remarriage, he was sent to Queensland with his older sister and younger brother in 1865 . There, the boys would live with their maternal uncle, John Mortimer, on Manumbar station, his sheep property in the south Burnett River valley, about $160 \mathrm{~km}$ north of Brisbane. ${ }^{3}$ Mathew remained in or near this area until 1876, as station hand, gold-digger or country school-master. He abandoned teaching in Queensland for the Presbyterian ministry in Victoria, but maintained a strong interest in and contacts with Queensland, especially the Kabi Kabi (who now prefer to

E.g., Berndt 1977, p. 538; Elkin 1958, pp. 226-227; Stanner 1968, p. 35; Cowlishaw 1986, p. 3. Elkin 1963, pp. 6-19; Elkin 1958, pp. 226-227; Elkin 1970, pp. 19-20; Cowlishaw 1986, p 3.

3. See Prentis 1992, pp. 466-480. 
call themselves Gubbi Gubbi) and Wakka Wakka (or Waka Waka) people, throughout his life.

The voyage out to Queensland was eventful and ended at the Quarantine station at Dunwich on Stradbroke Island. ${ }^{4}$ Aboriginal people had been moved out of the vicinity of the station for the sake of their health and to accommodate the immigrants. Life in quarantine was generally somewhat tedious. To relieve the tedium, there was the occassional birth, death, escape, fight and a bush-fire which lasted over a week and damaged the telegraph. Mathew first encountered Aborigines when they helped the immigrants fight the blaze.

Uncle John Mortimer met the boys and Jane at the wharf in Brisbane. Before heading up-country they stayed in Brisbane at the home of Tom Petrie, a member of the pioneer Scottish family, entrepreneur, explorer and 'friend of the Aborigines'. He spoke Kabi Kabi and later became one of the two best sources of information on the legends of the Kabi Kabi people.

The route to Manumbar took them via Durundur station, established by the Archer family from Scotland. Near the present town of Woodford, Durundur was about $100 \mathrm{~km}$ north of Brisbane. It was there, in April 1865, that John Mathew saw a large group of Aborigines for the first time. His recollection of that occasion 34 years later is revealing.

A bullock had just been slaughtered by the station hands, the blacks were congregated around the killing-place. A low white, with a feeling of gay superiority, swung the reeking, bleeding, lights and liver with a slap round the neck and on to the naked bosom and shoulders of an unoffending black woman. The gentle creature received this act of gallantry with a smile. I can never forget this disgusting insult and the meekness with which it was borne. It was at once an index and a type of much of the treatment which the natives have received from those who have taken their heritage away from them, and if the weaker side has retaliated is it to be wondered at? ${ }^{5}$

Mathew's humanitarian attitude was to be reinforced by his experience of life on his uncle's station and, with his eye for detail, was to provide the prerequisite for his studies of Aboriginal languages and societies in later years.

The five years John Mathew spent at Manumbar were crucial in that they introduced him to three great influences on his life: John Mortimer, the Aboriginal people and the Australian bush. Alec Mathew later recalled that Mortimer did not 'press us to do heavy work'. Soon after the boys' arrival at Manumbar in 1865, John Mathew started work on book-keeping and store-keeping. During shearing each year, he was busy every night with the shearers' tallies. He kept the times of the men engaged in sheepwashing, mustering, branding and other tasks. There were about a dozen shepherds at various points of the 100 square mile property and John would count out the rations for the pack horses to carry them out to the shepherds, some of whom were Aboriginal, twice a week. Some of the 20 or so musterers who brought the 2,000 cattle in for branding were Aboriginal as well. Most of the cattle were free-range and the boys later began

4. For a fuller account of the voyage and the sources on which it is based, see Prentis 1998, pp. 14-18.

5. Mathew 1899, pp. 81-82. 
to help with stock-riding. ${ }^{6}$ He also went on errands to Nambour and Maryborough, fairly hazardous journeys even in the $1860 \mathrm{~s} .{ }^{7}$ While 'shepherding sheep or tailing cattle [John Mathew] studied English Grammar, German, French and Latin'. ${ }^{8}$ He went further, as there is much evidence of geography and mathematics, with some science and a little Chinese as well. ${ }^{9}$

When John Mathew was working for his uncle, there were about 20 Kabi Kabi Aborigines employed on Manumbar, who camped there with their families. Mathew finished working on Manumbar in 1870, but went back for many visits afterwards. He got to know the Kabi Kabi people well-well enough for them to include both uncle and nephew in the tribe's classificatory kinship system. In the Kabi classificatory kinship system, John Mortimer was placed in Barang section. John Mathew, known as 'Young Mortimer' and as Mortimer's sister's son, was automatically assigned to Balkuin section. ${ }^{10}$ Like Mortimer, Mathew respected them as persons, though devalued their culture at first. He came to speak Kabi Kabi fluently and later told R.H. Mathews, another prominent 'amateur' ethnographer that 'very few whites knew the Kabi language so well as I did'. ${ }^{11}$ He reflected more deeply on and systematised that knowledge academically later.

One black employee saved him from drowning in a waterhole on Manumbar. This was Kagariu, alias Johnny Campbell, later a notorious bush-ranger who was hanged in 1880. Mathew was clearly fascinated by him and wrote an account of Campbell's career under the pen-name 'Walareyan' just after the execution. ${ }^{12} \mathrm{He}$ observed and remembered other incidents amongst the black employees on Manumbar which he was able to use later in analysing such matters as kinship. One incident concerned a 'tussle' between Kagariu and his wife. Kagariu called for help, not from the stronger of two men passing by, but from the younger and weaker, purely because he was in the same 'section' of the clan and was therefore a 'brother'. ${ }^{13}$

John Mathew's early interest in Aboriginal society and languages goes back to the personal rapport he developed with the Kabi Kabi people when working on his uncle's property in 1865-1870. He conducted more systematic field research in 1884, 1906-1909 and 1913, and even as late as 1923-24 while on his duty as Moderator of the General Assembly of the Presbyterian Church of Australia. He experienced Aborigines as friends first, rather than as scientific specimens, as was the case with Howitt and Spencer. He had first hand knowledge, especially of language, though he was not the first white man to know Kabi Kabi well, as Tom Petrie, whom he met in as 1865, had a very good knowledge of their language and stories. Mathew's continuing investigation

6. A. Mathew to R.Y. Mathew, 19 June 1929 (J. Mathew Papers, OM74-17, John Oxley library, Brisbane [hereafter JOL].

7. J. Mathew, Notebook kept on Manumbar (Mathew Papers, JOL).

8. J. Mathew to J. Mortimer, 1 July 1879 (Mathew Papers, JOL).

9. J. Mathew, Notebook (Mathew Papers, JOL).

10. Fergus 1929, p. 588; Mathew 1910, p. 137.

11. J. Mathew to R.H. Mathews, 11 December 1907 (R.H. Mathews Correspondence, diary and working notes, 1893-1918, MS 1606/1, Australian Institute of Aboriginal and Torres Strait Islander Studies [hereafter AIATSIS]).

12. See Appendix, person No. 13.

13. J. Mathew 1910, p. 137. See Appendix, persons 37-41. 
involved the application of scientific methods, and linguistic methodology, learned in the process of both his self-education in the 1870 s and university and theological studies in 1878 and $1882-86$.

Mathew's research did not begin, as did that of others of his contemporaries, with some abstract scientific curiosity or with a pre-digested theory to check or an overseas patron to supply. ${ }^{14} \mathrm{He}$ got to know Aboriginal people at a much younger age as his neighbours and fellow employees. He was on close terms with some and learned to understand and even speak their language before it became an object of linguistic study to him. There was thus at this time no ulterior motive in his relationship with Aborigines. He remained known to and even respected by them fifty or more years later in some cases. After all, he had been allocated a place in the Kabi Kabi's sectional kinship system. Therefore, when he later wrote or spoke of individual informants he was automatically in a relationship with them and, as well, he often knew them more deeply as persons than some more 'scientific' observers would ever know their informants. He usually knew their Kabi Kabi (or Wakka Wakka) names and remembered their social practices and stories they had told him. He respected the stories' integrity, whatever he thought of the factuality of their contents. He could recall and interpret incidents he had observed, such as the fight between Johnny and Nelly Campbell. The ethnographic significance of the practices and stories emerged and was analysed later.

As E.M. Curr put it, concerning Mathew's contribution to his The Australian Race,

I attribute the fullness of his description... rather to his love of ethnological studies, which had led him to observe and remember what came under his notice, than to that ripe knowledge which results from long experience.

As Elkin puts it, Mathew may have got 'the best of both worlds', by the combination of face-to-face contact and systematic enquiry. ${ }^{15}$

Unfortunately, there is oniy a little evidence in his note-books of the time of anything resembling 'field-work' conducted by Mathew while he lived in or near Kabi country from 1865 to 1875 . There are not quite three pages on 'the Kabee-kabee Dialect'. ${ }^{16}$ In many of his articles and in his books, however, he refers to observations made at that time. Many of these observations are repeated. For instance, Kagariu Johnny Campbell) is referred to in his paper given in 1889 to the Royal Society of New South Wales, Eaglehawk and Crow (1899) and Two Representative Tribes of Queensland (1910). 'My blackboy', who carried the message stick, is also mentioned in all three. ${ }^{17}$ These and some other black 'informants' show that he was observing the Aborigines closely while working at Manumbar. Jenny Lind he met as a little girl in the 1860s and again in $1906 .{ }^{18}$ This is but an extreme example of the way Mathew liked to renew old acquaintances but at the same time check the memories of his informants in order to verify evidence.

14. For instance, Baldwin Spencer had gone on the Horne Expedition to central Australia, where black bipeds had distracted his attention from the green frog.

15. Elkin 1975, p. 16.

16. Mathew papers, JOL.

17. Mathew 1889, pp. 338, 408; Mathew 1899, pp. 10, 114; Mathew 1910, pp. 124, 137.

18. Mathew 1910, pp. 148, 160, 165. See the Appendix, person 31. 
There is also more direct testimony by Mathew in his later works. In the preface to Two Representative Tribes he refers to being 'in constant touch' with Kabi Kabi and Wakka Wakka people for six years and intermittently for four years after that. ${ }^{19} \mathrm{His}$ first published work of scholarship was extracted from a letter he wrote to the Oxford Professor of Comparative Philology, Max Müller on 10 February 1879 from Mt Rothwell, Little River, Victoria, where he was managing a farm after completing one year at the University of Melbourne. Speaking of his Manumbar years, Mathew says of the Kabi Kabi language, 'I managed to learn something of its structure and to compile a vocabulary of some 600 words' ${ }^{\prime 20}$ This implies more than merely being observant: as his tantalisingly brief set of notes shows, he had been recording information. When through academic studies of English, Latin and Greek languages he acquired some interest and skills in linguistic analysis, the raw data was there to be studied.

He had read closely Müller's text, A Survey of Languages as well as the Rev. William Ridley's vocabularies of Kamilaroi and Dippil (a Kabi Kabi dialect) and a 'Mr Bunce's' vocabularies. ${ }^{21}$ This letter makes clear that his scholarly interest started with language. This is not surprising given his inclinations and the importance of language and literature studies in an arts degree and in theological studies. It prefigures the importance of language in his later ethnography and it was an aspect of scholarship in which he had the advantage over other pioneer anthropologists. Social practice and language reflect each other. Stories embody and language structures moral and social meanings. He was becoming well-equipped to learn from language about social structure and function.

In the three years of farm management between first and second year University, Mathew kept himself busy increasing his knowledge of ethnology and linguistics as well as how to apply it to his knowledge of the Kabi Kabi and also broaden that knowledge. In early 1880, he heard of the project of E.M. Curr (1820-1889) to compile information about as many tribes as possible, using the questionnaire method. On 6 April 1880, Mathew wrote to Curr offering to supply a Kabi Kabi vocabulary for his projected work. Curr accepted gladly and forwarded the list of 124 English words and the 83question questionnaire. ${ }^{22}$

Mathew responded to Curr's encouragement with his customary enthusiasm and returned the word list within a month. Curr sent his 'warmest thanks. It will be amongst my best contributions'. He also proposed that his young correspondent go further and suggested 'a short account of the tribe' based on the questionnaire (which was yet to be forwarded) and 'a Discourse on the Kabi language'. Curr found Mathew very obliging. He responded again very swiftly and Curr thanked him for taking 'so much trouble about this business'. The corroboree music sent was welcome, he suggested some pronunciation guides and told him to add more about the Kabi people if he wished. Above all, Curr said, he wanted 'FACTS'. ${ }^{23}$

19. Mathew 1910 , p. xxi.

20. Mathew 1880 b, p. 312 .

21. Ibid.

22. E.M. Curr to J. Mathew, 8 April 1880 Mathew Papers, MS 950 D; AIATSIS, Elkin 1975, pp. $12-$ 13.

23. E.M. Curr to J. Mathew, 7 May 1880, AIATSIS. 
Gradually, with Curr's encouragement, the chapter on the Kabi Kabi grew in size and scope, with Mathew gradually adding more and more to the section on social system and culture. The delay between the initial flurry of enthusiasm in 1880 and publication enabled Mathew to complete his B.A. and M.A. degrees, including some study of linguistics, and to do additional specific research. Some he did by mail, for instance with Uncle John Mortimer at Manumbar who confirmed some details about marriage rules and the section system of kinship. ${ }^{24}$ Then, at the end of his first year at the Theological Hall, 1884, he went north and spent September, October and November in Kabi Kabi country largely on field work to improve his chapter for Curr. With his facility with languages and knowledge of Kabi Kabi, and as he was well known to many Kabi people as 'young Mortimer', he could question the Kabi Kabi-speaking people in and around Manumbar very directly. The vocabulary was now built up to nearly 800 words, there were four pages of stories and dialogues and forty pages on the Kabi Kabi and their way of life. ${ }^{25}$ Curr's project grew into a massive four-volume work, published in 1886-87 by the Victorian Government Printer, and covering about 200 tribes. John Mathew's piece, no. 166, on the 'Mary River and Bunya Bunya Country' took up 58 pages in volume III (1887). It was one of the three best and most complete contributions.

In 1880, Mathew had also completed a manuscript which was not published, 'Career of Campbell. The Aboriginal Bushranger, by Walareyan'. From internal evidence, it was written in August 1880, just after Campbell was hanged in Brisbane. ${ }^{26}$ It is certainly in Mathew's handwriting. 'Walareyan' is not just a nom de plume; it was copied from an Aboriginal boy well-known to Mathew at Manumbar, and mentioned in Two Representative Tribes as deformed. ${ }^{27}$ Mathew family tradition states that Walareyan was a survivor of the native police raid on Manumbar in 1861. The boy must have made a strong impression: Mathew's son later lived in a house in the Melbourne suburb of Coburg named 'Walareyan'.

The contribution to Curr's project left Mathew wanting to do more. Despite marriage, career and fatherhood all commencing in 1887 and 1888, he continued to work hard at his ethnology and Aboriginal languages. While ministering at Ballan (1887-89), he broadened his interest beyond just the Kabi Kabi and their neighbours. He followed the standard practice of researchers of that era, by sending questionnaires to observers or collectors all over the country. ${ }^{28}$ He told his erstwhile pupil, Robbie Chirnside, in April 1888 of his activities.

I am still doing a little work in aboriginal lore making curious discoveries which are interesting to me if to nobody else and some of them may interest others some day. $^{29}$

24. J. Mortimer to J. Mathew, 21 November 1881 (Papers in possession Dr. J.Y. Mathew, East Hawthorn, Vic.).

25. Mathew 1887, pp. 152-209.

26. Mathew 1880a. On Johnny Campbell, see Prentis 1991, pp. 138-151 and for a corrected and augmented version, Prentis 1998, pp. 52-71.

27. Mathew 1910, p. 74

28. See Burgess 1987, especially Appendices 1 and 2 on Mathew's research methods and questionnaires. Copies of the questionnaires are in the Mathew Papers, MSS 950, 969, 999, AIATSIS, and a few originals are held by Dr J.Y. Mathew. 
One instrument was four foolscap pages, headed VOCABULARY OF AUSTRALIAN ABORIGINAL LANGUAGE. It gave phonetic advice for transcription and the end asked for any words additional to the 234 specifically requested, including any interesting sentences, 'lists of adverbs, and tables of declensions of nouns or pronouns, or the conjugation of any verb, whether complete or in part'. The list mostly consisted of nouns for topographical features, flora, fauna, parts of the body, attributes of people and numbers. There were pronouns but not many verbs. Some words sought were relationship names and some were religious in nature. There was also a one-page questionnaire of uncertain date requesting translations of English sentences. While the responses to these two language questionnaires would provide Mathew some insights into social structure and practice and cultural and religious life of the groups to which they referred, it was necessary to send out an ethnographic questionnaire, INFORMATION REGARDING AUSTRALIAN ABORIGINES, again four pages long, setting out three dozen questions dealing with the identity and location of the tribe or clan, its rules and terminology about marriage and relationship, its ritual and beliefs, material culture and even physiognomy. ${ }^{30}$ The introductory note illustrates the 'before it is too late' philosophy noted earlier and also Mathew's increased desire to systematise and render his enquiries more scientific and also reflects his successful linguistic studies at university and the Theological Hall.

In addition to the questionnaires, Mathew continued to conduct correspondence by letter on ethnographical matters with a smaller number of reliable informants. There is little evidence of this outside Kabi Kabi and Wakka Wakka country until rather later as, for instance, with correspondence with Daisy Bates in Western Australia. At this early stage, he wrote to friends on stations in the Wide Bay-Burnett area, such as James Steven at Taroom and George Anderson at Cow Wah, the latter of whom not only filled in the forms himself but organised others to do the same, conscientiously interviewing 'the blacks'. ${ }^{31}$

From these sources, Mathew was gleaning information from Victoria, north-west New South Wales, the Gulf of Carpentaria, the Monaro, north Queensland and elsewhere. The fruit of these questionnaires was not fully borne in time to be incorporated into Mathew's 1889 paper, but was very fully reported in Eaglehawk and Crow (1899). Most of the completed questionnaires are not dated and he kept blank forms to use for years afterward - for instance, some were filled in by himself on a field trip in 1923. It is clear many came in during the 1890s - for instance, the one from the Rev. Nicholas Hey of Mapoon on Cape York must have been from this period, because he only arrived there in 1891. Increasing quantities of published material were available in the 1890s, not least Curr's compilation, but he also closely read, inter alia, George Taplin on the Ngarinyeri, L.E. Threlkeld, William Ridley on the Kamilaroi, Fison and Howitt's Kamilaroi and Kurnai and R. Brough Smyth on Victoria.

29. J. Mathew to R.B. Chirnside, 9 April 1888, Chimside Papers, MS 11127, La Trobe Library, Melbourne [hereafter LTL].

30. Physiognomy was used as evidence to back up his reflections on possible 'racial mixing' in the origins of the Aborigines.

31. Letters in the Mathew Papers, MSS 950, 969, 999, AIATSIS and Mathew 1875-76, JOL and held by Dr J.Y. Mathew. George W. Anderson to J. Mathew, 20 January 1889 (Dr J.Y. Mathew). 
Between April and December 1888, his intentions became more serious and grew in scope, despite the new responsibilities of career and family. He told his former pupil, Robert Chirnside in December that he had 'been doing a good deal of work lately', especially on the languages. He had made some interesting 'discoveries' and was 'engaged in putting them into book form with a view to publication next year'. He added:

I have also a comprehensive work in contemplation and have begun to collect materials for it. I propose to make a survey of the whole of Australia and to gather up all matters of importance referring to Aboriginal Life and Language. This may occupy from ten to twenty years if I be spared, and if I don't live to complete it I have no doubt that somebody else will take up the work. ${ }^{32}$

This correspondence confirms that the questionnaires date from the second half of 1888. Mathew's words also show no awareness as yet of the internal politics of the small world of Australian anthropology. However, the ambition he displays, when fulfilled in his 1889 paper and more particularly in Eaglehawk and Crow, would thrust him unwillingly into controversy and polemic. He was about to move beyond straight ethnographic reporting into analysis and even theory, where 'patents' were jealously guarded. He brought to this new phase of his studies attitudes widely shared: for instance, the notion of 'before it is too late' and of a 'doomed race'. But he differed, too, in that he had had first hand, long-term 'natural' contact with Aborigines and was deeply sympathetic to the Aboriginal people. His knowledge of philology, skills at textual analysis and musical ability were also somewhat unusual and were to be useful. $\mathrm{He}$ was knowledgeable and astute enough to avoid some of the pit-falls facing the amateur anthropologist. He was also not in thrall to any overseas, armchair theorists, even though widely read in their works. He had a critical appreciation of evolutionary theory, though he rejected social evolutionary ideas.

In 1889, John Mathew submitted his long paper, almost book length, to the Royal Society of New South Wales. It won him the Society's bronze medal and prize of $€ 25$ for an original work of scholarship. The paper was published at the end of the year. ${ }^{33}$ The section on the description and classification of Australian languages was still rudimentary in scope and focussed on only two languages, nevertheless it took up over a fifth of the paper. He took up one of Curr's pet topics, the theory of the racial origins of the Aborigines and subjected it to critical scrutiny, along with those of several others and also presented his own theory. He took gentle issue with Fison and Howitt and the straight ethnographic reporting of family relationships provided raw material for Finnish ethnologist Edward Westermarck to question L.H. Morgan's 'group marriage' hypothesis which Fison followed. ${ }^{34}$

In the ten years between this paper and Eaglehawk and Crow, the accumulation and diversity of data increased. As Mathew's domicile allowed, he now began to delve into the languages and culture of the Victorian tribes in more detail. This was facilitated by

32. J. Mathew to R.B. Chirnside, 3 December 1888, Chimside Papers, MS 11127, LTL.

33. Mathew 1889, pp. 335-449 and 2 illustrations at the end of the volume; loc. cit., vol. XXIV (1890), p. 19.

34. Ibid., pp. 339-400; John Mathew to R.H. Mathews, 8 June 1898 (MS1606/4(b), AIATSIS); Westermarck 1891, pp. 321, 546. 
the return of more questionnaires during the 1890s. The extensive Scots Presbyterian clerical and pastoral network in Victoria no doubt helped. The Presbyterian Church's involvement with Aborigines in the Wimmera, at Coranderrk near Healesville north of Melbourne and at Ramahyuck in Gippsland provided him with an entree to Aboriginal communities, as well as contact with potential white informants who lived and worked with them, such as John Green and Joseph Shaw at Coranderrk. He visited Lake Tyers in 1890, and Coranderrk in 1891 and 1892. At Coranderrk, he met William Barak (18131903), sometimes called 'the last chief of the Yarra Yarra tribe', who had earlier been a very valuable informant for A.W. Howitt. Mathew was able to visit Aboriginal sites and communities during his annual vacation (sometimes spent at Healesville) and, in the early 1900s, when convener of the Church's Home Mission Committee, which was responsible for small, remote rural parishes, such as in the Wimmera. In July 1895, Mathew visited La Perouse in Sydney and interviewed several 'blacks and half-castes', taking advantage as usual of church duties.

John Mathew spent most of the October of 1906 in Kabi Kabi and Wakka Wakka country, mainly at Barambah Government Aboriginal Station, interviewing members of the two 'tribes', some of whom still remembered him. He retained some facility with spoken Kabi Kabi, an advantage lacked by most contemporary investigators. Barambah, renamed Cherbourg in 1931, is five kilometres from Murgon. It was established in 1905, initially for locals and people transferred from Deebing Creek Mission on Fraser Island and Durundur reserve near Caboolture. When Mathew visited Barambah in 1906, it was a raw, artificial community of several language groups numbering about 300 , but already well on the way to self-sufficiency. ${ }^{35}$ Mathew found that the time flew rapidly 'when...catechizing natives'. ${ }^{36}$ Lack of notes on this visit make the identification of informants difficult, although many of those mentioned in Two Representative Tribes would have been amongst them. ${ }^{37}$ One was Jenny Lind, whom he had met as a young girl: she was now a grandmother and 'Queen of the Wakka Wakka'. ${ }^{38}$ He met several of her family, which helped with kinship and totems as well as language among the Wakka Wakka. 'Old Peggy' and her family were very helpful in the same way for the Kabi Kabi. His interview with Peggy strayed as she interrogated him on spiritual matters. ${ }^{39}$ It is hard to imagine the scene with any other contemporary ethnographer. Another woman gave him a start in the neighbouring Gurang Gurang language.

In August 1907, when visiting Lake Condah mission in Victoria, he put his Kabi Kabi to unexpected good use in conversing with an amazed Mrs Maria MacDuff, a Kabi Kabi woman who lived there. ${ }^{40}$ As Tanggauwanan, she had been taken to Victoria forty years before as a young girl and later married Isaac McDuff, from Swan Hill. She knew more than just the language, and 'had her little finger taken off when a baby at [the] third joint by spider web being tied around. Mathew had actually known her brother Davy well in the 1870 s. Isaac, 190 centimetres tall and 108 kilograms, gave Mathew val-

35. Bleakley 1961, pp. 189, 199; Koepping 1977, pp. 159, 161, 162; Long 1970, pp. 102.

36. J. Mathew to D. Bates, 23 April 1907, Daisy Bates Papers, MS 365/97/folios 304-343, NLA.

37. Unless dated otherwise in Appendix, see for example, persons 7, 17, 27-29.

38. Steele 1983, pp. 243-244; Koepping 1976, pp. 32, 41.

39. Mathew 1907, p. 2. See Appendix, person 7.

40. Mathew 1910, p. 142; Maria MacDuff to J. Mathew, 12 September 1912, MS 950 (F) (9), (G), AIATSIS. See Appendix, person 1. 
uable information about hair types and the phratries (moieties), and also a long legend about an old crow. Mathew found the Lake Condah folk particularly informative. ${ }^{41}$ Five years later, after he returned from a trip to Queensland, he wrote to Mrs McDuff with news from her 'country', also asking after her health. ${ }^{42}$ This was surely an unusual degree of intimacy between informant and anthropologist.

In December 1907, he spent another day and a half at Lake Condah, taking down vocabularies and asking questions suggested by R.H. Mathews about myths, though not very productively. ${ }^{43}$ It was difficult, when not able to spend weeks on the task. Sometimes, other problems intervened: earlier that year a visit to Ramahyuck was aborted because of the terminal illness of the missionary, F.A. Hagenauer. ${ }^{44}$ In 1909, Mathew was busy again, taking copious notes on visits to Coranderrk, Lake Condah and Ebenezer in the Wimmera. His interest continued to be in language, stories, the totems and moieties and how they told each other apart. Monmoiko or Benjamin Manton at Ebenezer was very informative and consistent, as Mathew cross-checked some details three times over seven days. ${ }^{45}$ At Coranderrk, he found only about six of the 60 residents 'can give information regarding aboriginal lore, so that opportunities for research will soon be gone forever'. The young people were 'ignorant of the ... lingo ... and are practically Europeans'. The Mathew family attended the mission church; John Mathew spoke at the service and a young woman sang a Sankey hymn to her own harmonium accompaniment. ${ }^{46}$ Again, it was an unusual proceeding during 'scientific research'.

In 1908, Mathew renewed contact with his London ally, Professor A.H. Keane, asking him to write the preface for the new book he was writing on the Kabi Kabi and Wakka Wakka, which he was only too glad to do. Keane also seems to have been instrumental in persuading Fisher Unwin to publish it. He may even have suggested the title, Two Representative Tribes of Queensland, which fitted neatly in style with the recent titles by Howitt and Spencer. ${ }^{47}$ In July 1910, 500 copies of Two Representative Tribes were published by Unwin. ${ }^{48}$ Mathew's second book did not create anywhere near the same controversy as his first, although it was almost as widely reviewed. ${ }^{49}$ More than half the volume now dealt with social structure and way of life of two specific tribes in some

41. J. Mathew, Notebook, MS950(F)(9), AIATSIS. See Appendix, persons 1 and 61 for further details.

42. M. MacDuff to J. Mathew, 12 September 1912, Mathew Papers, MS950, AIATSIS. An annotated transcript of the letter has been published in Church Heritage, vol. 9, no. 3, March 1996, pp. 191-194.

43. J. Mathew to R.H. Mathews, 11 December 1907, R.H. Mathews Correspondence etc., MS 1606/ 1 , AIATSIS.

44. J. Mathew to R.H. Mathews, 6 June 1907, R.H. Mathews Correspondence etc., MS 1606/1, AIATSIS.

45. J. Mathew, Notebooks, MS950 (F) (1), (6) and (9), AIATSIS. See Appendix, person 62

46. Mathew 1909, pp. 1-2. According to Barak's biographer, the Coranderrk folk 'remained staunchly Presbyterian': see Wienecke 1984, p. 56.

47. J. Mathew to R.H. Mathews, 4 May 1908, 17 August 1908, 11 February 1909 , R.H. Mathews Correspondence etc., MS 1606/1, AIATSIS; A.H. Keane to J. Mathew, 19 February 1908, 16 October 1909, Mathew Papers, n.d., MS 950, AIATSIS.

48. Publishing Notes in Mathew Papers, n.d., MS 950, AIATSIS.

49. E.g. Nature, 29 December 1910 (no author); Man, vol. X, no. 9, pp. 139-140 (by 'B.M.'). 
depth and so the controversial matters in the first chapter on origins did not bulk large in the comments. However, Keane's preface gave strong support to Mathew's origin theories and defended his scholarship against 'step-motherly' treatment by certain 'leading authorities'. He was, Keane asserted, 'immeasurably better informed than any of his opponents, Dr Howitt alone excepted'. ${ }^{50}$ This support may also help to explain the more positive reception.

Between 1907 and 1913, Mathew's reputation definitely improved. Fison and Howitt died, he was reconciled with Spencer and was Vice-President of Anthropology at the 1913 A.A.A.S. Meeting. In June 1910, he read a paper to the Royal Historical Society of Victoria on pre-contact Victorian Aborigines, using linguistic evidence to highlight issues such as the close relationship of Victorian and Tasmanian Aborigines. ${ }^{51}$ At the 1913 Meeting of the A.A.A.S., he presented material on the Gurang Gurang, neighbours of the Wakka Wakka and who had been settled at Barambah with them when he visited in 1906, 1912 and 1913. ${ }^{52}$ The visits of 1912 and 1913 enabled double-checking earlier evidence as well as collecting new material. He continued to pursue the notion of 'light' and 'dark blood' classes (phratries or moieties), confirmed matrilineality and, in 1912, the Gurang Gurang vocabulary. ${ }^{53}$ He was also able to question residents from as far afield as northern New South Wales and Burketown, on language, religious beliefs and practices, sorcery as well as relationships. ${ }^{54}$

In the middle of July 1914, the Coburg manse was visited for four days by David Unaipon (1872-1967), a Narrinyeri (Ngarrindjeri) man from Point Macleay, South Australia, well-known as a lay-preacher, author and inventor. The manse children were intrigued by his ideas about the feasibility of perpetual motion, but their father made good use of the visit and took down nine pages of notes, mainly legends, including an eaglehawk and crow story. Unaipon's desire to link Aboriginal and Christian spirituality is apparent in a story about a 'great and good Spirit whom they called the Father'. There was also information about words and relationships. ${ }^{55}$

John Mathew continued to extend his research, although it was interrupted badly by the Great War and by the preparation of his D.D. thesis in 1922 and 1923 . When Moderator-General, in 1923 and 1924 he revisited Queensland and his old haunts. His penultimate visit was at the age of 75, in September 1924, before attending the Church's General Assembly of Australia in Sydney. He found the Burnett at Murgon in flood, and drove a hired jinker across a flooded creek to Barambah. As he told his wife:

I had a rare time with the blacks. Two old gins remembered me and were in ecstasy. One stretching out her hand said "Put it there." Another cried out "Kabarow! Kabarow! Kabarow!!" ["Well done!" in Wakka Wakka] This was Jenny

50. A.H. Keane, Preface to Mathew 1910, p. xiii.

51. Mathew 1911, pp. 79-89.

52. Mathew 1913, pp. 433-443.

53. Brisbane Courier, 6 August 1912.

54. J. Mathew, Notebook, MS 950 (F) (6), AIATSIS.

55. J. Mathew, Notebook, MS 950 (Aa) (3) (ii); R.Y. Mathew, note in MS 950 (E) (1), AIATSIS. Unaipon spent some time in Melbourne in 1914. He gave a lecture to the Royal Geographical Society on the history of his people and received financial assistance from new friends: see Jenkin 1979, pp. 251-252. See Appendix, person 77. 
Lind the half caste-a wonderful vigorous specimen for 70 years of age ... I have added a little to my stock of folk-lore. ${ }^{56}$

Allowing for changing idiom, there is more respect and affection between researcher and subject expressed here than was customary, even in the 1920s. He returned the next month; he revisited Barambah on 8th October, taking down words there from Harry Ord, a speaker of Kiramai, the Herbert River language. He was continuing to send out questionnaires. These investigations and a visit to Lake Tyers in June provided information for an article in the Australasian in $1925^{57}$ and four papers given to the A.A.A.S. meeting in Perth in 1926. The latter incorporated vocabularies of four languages of Queensland, and a substantial synthesis of research on Aboriginal religious beliefs and practices. ${ }^{58}$ It was in the same year that he and Baldwin Spencer were appointed to the Anthropology Committee of the Australian National Research Council. They were the only living links between the pioneers of systematic anthropology and universitytrained, fully professional scholars and field workers. Equally symbolically, they both died in 1929.

There are both similarities and differences between the other pioneers of anthropology and John Mathew. Unlike several of his colleagues, he was not acting as a local 'agent' for overseas theorists in search of evidence to bolster their theories ('jackals' to the 'lions', as Mathew put it). He did attempt later to find overseas allies, but only in self-defence. Indeed, his challenges to some of the pet theories of his contemporary Australian scholars were not motivated by preconceived theory, but by what he observed and was told by Aboriginal people. His fieldwork was perhaps more opportunist than some of his contemporaries in the sense that he was a very busy man with many other duties and interests, and would do research where, when and with whom he could. Admittedly, in later years, he was particularly interested to ask questions related to his own theories, but he collected data about anything (e.g. the music for a corroboree) from any Aboriginal person he encountered, male or female, young or old, Christianised or not.

Considering the importance of language in Mathew's work, few of the identified informants (nine) are specifically referred to concerning language or vocabulary. This may be attributed to the fact that the bulk of his information on Kabi Kabi came from actually learning to speak it as a living language in the 1860s. This was augmented, deliberately in the case of Wakka Wakka and Gurang Gurang, and incidentally with other tongues, while interviewing individuals on other matters in 1884,1906, 1913 and 1924 . His posted questionnaires of the 1880 s and after also yielded much vocabulary, especially of other languages.

Only eight specific references are made to informants in relation to myths and legends, when the 'Eaglehawk/Crow' motif was very important to Mathew's origin theory. Again, he picked up Kabi Kabi and Wakka Wakka material in the 1860s, and much published research by others on other parts of the continent was also ransacked for

56. J. Mathew to W. Mathew, 7 September 1924, from Murgon, quoted, Mathew 1973, p. 189 (original in possession of Dr. J.Y. Mathew).

58. Mathew 1926a, pp. 524-540; Mathew 1926b, pp. 540-547; Mathew 1926c, pp. 547-550; Mathew 1926d, pp. 551-552. 
folklore. Some came from correspondence, for example with Daisy Bates in Western Australia.

Many more informants are mentioned in relation to real or perceived differences in physical appearance of people, especially in relation to real or perceived differences between 'phratries' (moieties), another element in Mathew's trihybrid origin theory. Subjects canvassed included 'dark and light blood' (5), skin colour (3), stature (2), hair colour or curliness (10) and general appearance (4).

The most common uses of informants' material was to illustrate discussions of 'phratries' (moieties) or 'classes' and sections (36) and totems (14). Other matters of interview specifically noted included also religious matters in general (3), and seven dealing with the overlapping matters of healing, magic, quartz crystals and clever men and one on initiation. Funerary and courting customs, artefacts, points of the compass and infanticide are also discussed in relation to specific informants. His treatments of a range of other subjects, such as arithmetic and numbers and body decoration, do not refer to named or identified informants,

Of the identified 77 (witting or unwitting) informants listed in the appendix, 54 were male and 23 female. Mathew seems not to have intruded much on secret business, or sexual matters, except in fairly general terms. He seems from his own account to have got on as well with women as men, the incident at Durundur when he was not quite 16 showing evidence of a degree of respect for an unknown Aboriginal woman. The ages of his informants varied a good deal, but many of those who were elderly he had known when they were young. Most of his person-to-person work in Victoria was between the 1890 s and 1912 , so naturally he dealt there with mostly older people who remembered the 'traditional' ways better.

Mathew was aware of the pitfalls of talking to Aboriginal informants in English, which he had to do in Victoria, and was able to use Kabi Kabi and to an extent Wakka Wakka in interviews in Queensland. Acculturation needed to be 'peeled away', especially when he was dealing with Aboriginal Christians. However, it was not always clear how much acculturation had affected memories especially of the old religious beliefs. Mathew strongly affirmed that the Aborigines indeed had religion and that they were aware of a kind of 'all-Father' or supreme being. A good example of this dilemma was the few days he spent in 1914 with David Unaipon, who later published 'native legends' in a form compatible with his evangelical Christian beliefs. On a personal level, Mathew was quite keen to identify with and encourage them as fellow Christians.

As far as listed informants were concerned, most were contacted at or about Manumbar and Yabba in the 1860s and 1884, at Barambah Aboriginal station in 1906, 1912, 1913 and 1924 and at Victorian stations Ebenezer (one), Ramahyuck (one), Lake Tyers (one), Coranderrk (two) and Lake Condah (12). There were clearly others of whom record is lost, especially in case of Coranderrk, which he visited several times and the visit to La Perouse in 1895 yielded only one identified informant and little useful information. The exposure to Kabi Kabi and Wakka Wakka culture was most sustained. In the case of Victorian people, Mathew had to be content with shorter but more frequent visits to build up rapport and confidence. With revisits, especially to Lake Condah, he was able to check informants' memories and consistency by going over 
some points three times in different ways. So, by adding a day or two at a time, he was able to cover and re-cover a lot of ground, especially at Lake Condah.

The interviewing methods of John Mathew were clearly not the same as more recent academic anthropologists, nor did he immerse himself to the degree some have done. It could be said that relationships of personal friendliness would have compromised his and his informants' 'objectivity' or accuracy. Inevitably, especially in Victoria when he was a clergyman, he was an authority figure, however friendly. Being associated with acceptable white people like John Green or Joseph Shaw or Ann Fraser Bon at Coranderrk would have helped him in some ways, but a too close association with figures like Hagenauer at Ramahyuck could easily have constrained both his informants' answers and his questions. At Barambah, on the other hand, he had the advantages of language facility, long-term familiarity and being actually related to the people he interviewed as a member of the Balkuin section of the Kabi Kabi, and also not being the government.

Despite being a white male authority figure, Mathew had various factors in his favour to put informants at their ease, not least his tact and his boyish enthusiasm. To attend chapel with the residents of Coranderrk and write to Maria MacDuff at Lake Condah were not the usual duties of an anthropologist. His less formal relationships with some of his informants could shake loose incidental, unexpected or unusual information on Maria MacDuff's missing little finger or Harry Ord's reference to dilly bags.

While those of John Mathew's Aboriginal informants who were, in some sense, friends but were also sometimes unwittingly scientific specimens or case-studies, they did not cease to be friends, albeit different from his white friends. It was not that they were inferior: he was strongly wedded to the Christian belief in the equality of all persons in the eyes of the Creator and he was also in awe of the richly nuanced languages and highly elaborate kinship systems of Aboriginal societies.

Though he was able to speak to a wide range of Aboriginal people on many subjects, he was heavily constrained by the nature of his calling, whereby he was restricted not only in time but geographically spread. He had to rely for information on inland tribes on informants who found themselves shipped off to stations like Barambah, such as Harry Ord, Wai (Maggie McLean) and Fred Ingham (numbers 72, 49 and 44).

The question whether Mathew's often less formal relationships with informants was a help or a hindrance to his anthropology yields no definitive answer. It was both. Considerations of Victorian manners and of Aboriginal secrecy limited direct information on sacred and sexual matters, but did not entirely prevent research on those matters. Matters of folklore and language were probably more forthcoming, given Mathew's interests and his ability to commuricate. Some of his friendly informants were eager to please, and this could cut both ways. On occasions, they no doubt told him what he wanted to hear as well as occasionally delving into some more personal and family matters. It is hard to imagine another anthropologist being asked to look out for his informant's daughter who had moved to the big city, let alone doing it.

Malcolm Prentis is Senior Lecturer in History at Australian Catholic University (New South Wales), where he has taught Aboriginal history for ten years. His book Science, Race and Faith: a Life of John Mathew was published in 1998 


\section{References}

Berndt, Ronald M. \& Berndt, Catherine H. 1977, The World of the First Australians , 3rd ed., Dee Why, NSW.

Bleakley, J.W. 1961, The Aborigines of Australia: their History - their Habits - their Assimilation, Brisbane, 1961.

Burgess, G.W. 1987, Reverend John Mathew-Contributions to the Study of the Australian Aborigines, B. Litt. Thesis, Australian National University.

Cowlishaw, G.K. 1986, 'Aborigines and Anthropologists', Australian Aboriginal Studies, Vol. 1, pp. 2-12.

Curr, E.M. 1886-7, The Australian Race: Its Origins, Languages, Customs, Melbourne.

Elkin, A.P. 1958, 'Anthropology in Australia: one chapter', Mankind, Vol. 5, no. 6, pp. $225-42$.

- 1963, 'The development of scientific knowledge of the Aborigines', in Australian Aboriginal Studies, ed. H. Sheils, Melbourne, pp. 3-28.

— 1970, 'Before it is too late', in Australian Aboriginal Anthropology, ed. R.M. Berndt, Perth, pp. 19-28.

— 1975, 'R.H. Mathews: his contribution to Aboriginal studies', Part I, Oceania, vol. 46, no. 1, pp. 1-24.

Fegus, R.M. 1929, 'The Rev. John Mathew, D.D.', Presbyterian Messenger, 22 March 1929, p. 588.

Jenkin, G. 1979, Conquest of the Ngarrindjeri, Adelaide.

Koepping, K-P. 1976, 'How to remain human in an asylum: some field-notes from Cherbourg Aboriginal Settlement in Queensland', Occasional Papers in Anthropology, vol. 6, no. July, pp. 28-47.

_- 1977, 'Cultural pattern on an Aboriginal settlement in Queensland', in Aborigines and Change: Australia in the 1970s, ed. R.M. Berndt, Canberra, pp. 159-76.

Long, J.P.M. 1970, Aboriginal Settlements: a Survery of Institutional Communities in Eastern Australia. Canberra.

Mathew, J. 1880a, Career of Campbell. The Aboriginal Bushranger, MS, AIATSIS, IA(d)9,.

- 1880b, 'The Kabi Dialect of Queensland', Journal of the Anthropological Institute, vol. 9, pp. 312-316.

1887, 'No 166. Mary River and Bunya Bunya Country' in The Australian Race, ed. E.M. Curr, Melbourne, vol. III, pp. 152-209.

- 1889,'The Australian Aborigines', Journal and Proceedings of the Royal Society of New South Wales, vol. XXIII, pp. 335-449; vol. XIV: p. 19.

- 1899, Eaglehawk and Crow, Melbourne. 1907, 'A Philosophical Black Gin', Coburg Presbyterian Chronicle, January, p. 2 1909, 'The Coranderrk Aboriginal Settlement', Coburg Presbyterian Chronicle, No. February, pp. 1-2.

- 1910, Two Representative Tribes of Queensland, London.

1911, 'The origin, distribution, and social organization of the inhabitants of Victoria before the advent of Europeans', Victorian Historical Magazine, vol. I, No. Sep- 
tember, pp. 79-89.

-1913, 'Note on the Gurang-Gurang tribe of Queensland, with vocabulary', Report of the Fourteenth Meeting of the Australasian Association for the Advancement of Science, vol. 14, pp. 433-443.

— 1925, 'Gleanings in Aboriginal magic', The Australasian, 7 March1925.

1926a, 'The religious cults of Australian Aborigines', Report of the Eighteenth Meeting of the Australasian Association for the Advancement of Science, pp. 524-540.

- 1926b, 'Vocabulary of the Wakka Wakka', Report of the Eighteenth Meeting of the Australasian Association for the Advancement of Science, pp. 540-547.

- 1926c, 'Vocabulary of (i) the Kiramai Language, Herbert River, Queensland, and of (ii) the Wulili Language, Augurn, Redbank, Camboon, Walloor on the Dawson', Report of the Eighteenth Meeting of the Australasian Association for the Advancement of Science, pp. 547-550.

- 1926d, 'Vocabulary of the Kitapul, spoken about Allora, Killarney and generally the source of the Condamine and the Logan River', Report of the Eighteenth Meeting of the Australasian Association for the Advancement of Science, pp. 551-552.

Mathew, R.Y. 1973, John Mathew 1849-1929, John Oxley Library, Mitchell Library, author's possession.

Prentis, M.D. 1991, 'The Life and Death of Johnny Campbell', Aboriginal History, vol. 15, no. 1-2, pp. 138-151.

_ 1992, 'John Mortimer of Manumbar and the 1861 Native Police Inquiry in Queensland', Journal of the Royal Historical Society of Queensland, vol. XIV, no. 11, pp. 466480.

1998, Science, Race and Faith: a Life of John Mathew, 1849-1929. Sydney.

Stanner, W.E.H. 1968, After the Dreaming: Black and White Australians - an Anthropologist's View. Sydney.

Steele, J.G. 1983, Aboriginal Pathways in Southeast Queensland and the Richmond River, St. Lucia, Queensland.

Westermarck, E. 1921, The History of Human Marriage, 2nd ed., 3 vols, London.

Weinecke, S. 1984, When the Wattles Bloom Again: The Life and Times of William Barak Last Chief of the Yarra Yarra Tribe, Woori Yallock, Victoria. 


\section{Appendix: John Mathew's Aboriginal informants}

Unlike some of his contemporary anthropologist colleagues, John Mathew frequently named his Aboriginal informants. Sometimes, he adds interesting personal details which might be strictly speaking irrelevant to the point he is making. The list below is based on published works and research notes. It includes not only those interviewed in any formal sense but also persons he simply knew in the 1860 s or observed. It does not include all individuals to whom reference is made in written questionnaires or in the papers and books of other scholars.

\section{Abbreviations}

AAAS Reports of the Australasian Association for the Advancement of Science.

CPC Coburg Presbyterian Chronicle

Curr J. Mathew 'No. 166-Mary River and Bunya Bunya Country,' in The Australian Race by E.M. Curr (Melbourne: Government Printer, 1887), vol. III, pp. 152-209.

RSNSW J. Mathew, 'The Australian Aborigines,' Journal and Proceedings of the Royal Society of NSW, XXIII (1889), pp. 335-449.

E EC J. Mathew, Eaglehawk and Crow (Melbourne: Melville, Mullen \& Slade, 1899).

TRTQ J. Mathew, Two Representative Tribes of Queensland (London \& Leipzig: T. Fisher Unwin, 1910).

JRAI J. Mathew, 'The Origin of the Australian Phratries and Explanation of some of the Phratry Names,' Journal of the Royal Anthropological Institute, XL (1910), pp. 165-170.

Steele J.G. Steele, Aboriginal Pathways in Southeast Queensland and the Richmond River (St Lucia, Qld: University of Queensland Press, 1983).

VHM J. Mathew, 'The Origin, Distribution, and Social Organization of the Inhabitants of Victoria before the Advent of Europeans,' Victorian Historical Magazine, I (September 1911), pp. 79-89.

Contents

\begin{tabular}{|ll|ll|}
\hline $\begin{array}{l}\text { Informant num- } \\
\text { bers }\end{array}$ & State & $\begin{array}{l}\text { Informant num- } \\
\text { bers }\end{array}$ & State \\
\hline $1-49$ & $\begin{array}{l}\text { Queensland } \\
50-71\end{array}$ & $72-76$ & New South Wales \\
\hline
\end{tabular}


Comments on informant details

AGE [of the informant] Language group

Clan

Reference in published works

Reference in notes, letters etc.
Aboriginal name
European name
Where contacted
Age
Language group
Clan
Locality of origin
Other comments

Reference in published works

Reference in notes, letters etc.

Date of contact

Topics covered

Purpose of published reference

2
Aboriginal name
European name
Where contacted
Age
Language group
Clan
Locality of origin
Other comments

Reference in published works

3 Aboriginal name

Where contacted

Language group at the time of meeting Mathew

what some might call 'tribe', mostly Kabi Kabi or Wakka Wakka

the local group or 'horde' within the wider 'tribe' by John Mathew

unless noted otherwise, held by AIATSIS
Tanggauwanan

(Mrs) Maria McDuff

Lake Condah, Vic.

$60+$ ?

Kabi

Gundabora

12 miles from Maryborough, Qld.

-Moved to Vic. ca. 1867

-Married to Isaac McDuff, from NW Vic.

-Dherwain-gan section

- Opossum totem (muroirai)

-Batjala dialect, Fraser Island

TRTQ, 142, 160

MS950 (F) (9), (G)

$14 / 8 / 1907$

Language

-classes' and bloods

- Language

-religion

\section{Yanbirinya}

Davy

S.E.Qld

Young

Kabi

Gigabora

Widgee

-Mrs McDuff's brother (see no. 1), or once

betrothed to her

-Barang class

- Nguruin (emu) totem

TRTQ, 146

\section{Wanggumbalu}

S.E. Qld, not met,

Kabi 
Clan

Locality of origin

Other comments

Reference in published works

Purpose of published reference

4
Aboriginal name
Where contacted
Language group
Clan
Locality of origin
Other comments

Reference in published works

Purpose of published reference

5 Aboriginal name

Where contacted

Age

Language group

Other comments

Reference in published works

Date of contact

6 Aboriginal name

Where contacted

Language group

Other comments

Reference in published works

Date of contact

Purpose of published reference

$7 \quad$ European name

Where contacted

Age

Language group

Other comments

Reference in published works

Date of contact

Purpose of published reference

8 European name

Where contacted

Age

Language group

Other comments
Gundabora

South of Mt Boppel, Near Maryborough

- Father of Mrs McDuff

- Balkuir section

- Opossum totem (koroi)

TRTQ, 146

Phratries, 'classes' and totems

Bondobin

not actually met, S.E. Qld.

Kabi

Dauwabora

North of Mt Boppel

- Mother of Mrs McDuff

- Bondagan section

TRTQ, 146, 170

Phratries, 'classes' and totems

Walareyan's twin sister (see no. 13)

Manumbar

infant

Kabi

Killed as infant

TRTQ, 74-5

$1860 \mathrm{~s}$

Kilkoi

Manumbar

Kabi

Dherwain section

TRTQ, 137,177

$1860 \mathrm{~s}$

'classes', quartz

Peggy

Barumbah

'old'

Kabi

Mother of Arthur (no. 25)

TRTQ, 148

CPC, Jan 1907

Oct. 1906

Table of relationships

\section{Donald}

Manumbar

boy

Kabi

Lame from knife wound 
Reference in published works

Date of contact

9

European name

Other comments

Reference in published works

10

\section{European name}

Other comments

Reference in published works

Purpose of published reference

11 European name

Where contacted

Language group

Other comments

Reference in published works

Date of contact

Purpose of published reference

12

Aboriginal name

Where contacted

Age

Language group

Other comments

Reference in published works

Date of contact

Purpose of published reference

13
TRTQ, 123

Curr, 176

1860 s

Dick

Married to Fanny (no. 10)

TRTQ, 75

\section{Fanny}

Married to Dick (no. 9)

TRTQ, 75

Skin colour and statue

\section{Dougal}

Manumbar; Yabber Station

$\mathrm{Kabi}$

'poor, unfortunate wretch'

-handsome (high forehead, small nose)

-hanged: demoralised by goldfields

TRTQ, 75

$E \& C, 77$

RSNSW, 386

$1860 \mathrm{~s}$

Skin colour (TRTQ), Appearance (E E C).

\section{Buyu Marom (name means 'fat calves')}

Manumbar

elderly in 1888

Kabi

Very attached to J. Mortimer and mourned his passing (in 1888); may have been 'Jerry' (see Prentis 1998: 31).

TRTQ, 107

$1860 \mathrm{~s}$

Mourning customs

Walareyan

Manumbar

boy

Kabi

-arm difigured

-a twin (see no. 5)

-name used in poem for a place; son's house in

$$
\text { Coburg }
$$

TRTQ, 74

1860 s

Date of contact

Topics covered 
14

European name
Age
Language group
Locality of origin
Other comments
Reference in published works

Aboriginal name
Where contacted
Age
Language group
Other comments
Reference in published works
Date of contact
Purpose of published reference

Aboriginal name
Where contacted
Language group
Other comments
Reference in published works
Date of contact
Purpose of published reference

\section{European name}

Where contacted

Age

Language group

Clan

Reference in published works

Date of contact

Topics covered

Purpose of published reference

\section{European name}

Where contacted

Age

Language group

Locality of origin

Reference in published works

Purpose of published reference

European name

Where contacted

Age

Language group

Date of contact
Billy Lillis

fl. $1890 \mathrm{~s}$

Kabi

Yabba?

criminal

pic, TRTQ?

'one black boy'

Manumbar

boy

Kabi

yellowish-brown hair

$E \in C, 75$

RSNSW, 384

1880s

Colour of hair

\author{
'a blackfellow' \\ Cow Wah, Qld. Woodford \\ Kabi \\ via George $W$. Anderson \\ $E \mathcal{E} C, 118$ \\ 1890 s \\ Description of initiation
}

\author{
(a woman) \\ Barambah? \\ older \\ Gurang Gurang \\ Burnett River \\ AAAS (1913), 434 \\ 1906? 1913? \\ Gurang language \\ Vocabulary
}

\section{Tommy Cain}

Yabba, Qld/Manumbar, Kenilworth area.

Elderly in 1907

Kabi

Yabba

TRTQ, 74

his curly hair

Ball Jakka

Yabba area, Qld (via James Stevens)

Probably $60+$

Kabi

8 March 1907 (letter) 
Topics covered

20

European name

Where contacted

Age

Language group

Date of contact

Topics covered

21

European name

Where contacted

Age

Language group

Date of contact

Topics covered

22 Aboriginal name

Age

Language group

Locality of origin

Reference in published works

Purpose of published reference

23

\section{European name \\ Where contacted}

Age

Language group

Other comments

Reference in published works

Date of contact

Purpose of published reference

24 Aboriginal name

Other comments

Reference in published works

Purpose of published reference

25

Other comments

Reference in published works

Purpose of published reference

Big man, station worker, musket wound on forehead-great 'witch doctor' immune to bullets

\author{
Old Stubbins \\ Yabba area, Qld (via James Stevens) \\ Elderly \\ Kabi \\ 8 March 1907 (letter) \\ Magic; quartz crystals. A 'clever man', healed \\ Tommy Cain (no. 18)
}

\section{Old Sunday}

Yabba area, Qld (via James Stevens)

Elderly

Kabi

8 March 1907 (letter)

Magic

Tindabalu

$60+$

Kabi

Gympie

TRTQ, 71

migration stories

'my blackboy'

Manumbar

late teens

Kabi

Poem "The Aboriginal Loveletter" in Australian

Echoes

TRTQ, 124

Curr, 176

$E \& C, 114$

$1860 \mathrm{~s}$

message stick

Dwangin

Killed all her babies at birth

TRTQ 166

Infanticide

'one man I knew'

A 'clever man'

TRTQ, 176

About magic 
26
Aboriginal name
Language group
Other comments

Reference in published works

27
Aboriginal name
European name
Language group
Other comments

Reference in published works

Date of contact

Purpose of published reference

28
Aboriginal name
European name
Where contacted
Language group
Other comments

Reference in published works
Aboriginal name
European name
Where contacted
Language group
Other comments

Reference in published works

30
Aboriginal name
Language group
Other comments
Reference in published works

31 Aboriginal name

European name

Where contacted

Age

Language group

Other comments
Munojan

Kabi

-father of Arthur (no. 27)

-Balkiun section

-Kangaroo totem

TRTQ, 148

Bujirgundau

Arthur

Kabi

- Dherwain section

-Emu or bunya totem

TRTQ, 148

1906 ?

- Phratries, 'classes' and totems

-Table of relationships

Jiani

Charles Beattie

Barambah

Wakka?

-Joroin section

-Goanna totem

TRTQ, 148

\section{Mujinbi}

Aggie

Barambah

Wakka

-married to Jiani (Charles Beattie), no. 28

- Banjurgan section

-Sugar-bag or honey-ant (gayer) totem

TRTQ, 148

\section{Kuneraman}

Kabi

father of Peggy

TRTQ, 148
Mal
Jenny Lind
Barambah
elderly in 1924
Kabi/Wakka?
-'half caste'
-Baranggan section
-Bunya tree totem 
Reference in published works

Date of contact

\section{European name \\ Where contacted \\ Language group \\ Other comments}

Reference in published works

Date of contact

\section{Aboriginal name \\ European name \\ Where contacted \\ Language group \\ Other comments}

Reference in published works

Date of contact

\begin{abstract}
Aboriginal name
Language group

Other comments
\end{abstract}

Reference in published works

Purpose of published reference

35
Aboriginal name
European name
Language group
Other comments
Reference in published works
Date of contact

TRTQ, 148, 160, 165

Steele, 243-4

1870s, 1906, 1924

Kitty

Barambah?

Wakka

- Mother of Jenny Lind (no. 31)

- Banjurgan section

-Bunya tree totem

TRTQ, 148

1870 s?

\section{Maranger}

Mary

Barambah

Wakka

-Daughter of Janny Lind (no. 31)

- Banjurgan section

- Bunya tree totem

TRTQ, 148

1906

\section{Kanan}

Kabi

- Father of Mickey (no. 35)

-Barang section

-Turkey totem

TRTQ, 148

sections and totems

Bulir

Mickey

Kabi

-Husband of Jenny Lind (no. 31)

-Dherwain section

TRTQ 148,160

1860s?

\section{Buwanor}

Ben

Barambah

Wakka

-Jenny Lind's son (no. 3I)

- Banjur section

-Bunya tree totem

TRTQ, 148

1906

sections and totems 
37

Aboriginal name
Language group
Other comments

Reference in published works

\section{Aboriginal name \\ Where contacted \\ Language group \\ Locality of origin \\ Other comments}

Reference in unpublished works

\begin{abstract}
Aboriginal name
Language group

Locality of origin

Other comments
\end{abstract}

Date of contact

Purpose of published reference

\section{Aboriginal name \\ European name \\ Where contacted}

Age

Language group

Locality of origin

Other comments

Reference in published works

Reference in notes, letters etc

Date of contact

Purpose of published reference

41

European name
Where contacted
Age
Language group
Other comments
Reference in notes, letters etc
Date of contact

Bual

Kabi

second husband of Kami, father of Kilkaibriu

(no. 39)

'Career of Campbell' MS, 2

\section{Kami (female)}

not met

Kabi

Yabba?

Mother of Johnny Campbell (b. 1846) (no. 40)

'Career of Campbell' MS, 2

\section{Kilkaibriu}

Kabi

Yabba

- Half brother of Kagariu (no. 40)

-Six feet tall

-Son of Bual

1860s

height (over $6 \mathrm{ft}$ )

\section{Kagariu}

Johnny Campbell

Manumbar

c. $1834-1880$

Kabi

Yabba

- Bushranger

- Hanged for rape

-Very ugly, 5 ft 3in, strongly built

-Dherwain section

TRTQ, 137

$E \mathcal{E} C, 10$

RSNSW, 338

'Career of Campbell,' MS.

$1860 \mathrm{~s}$

Height contrast with brother ( $6 \mathrm{ft}$ or so)

Nelly Campbell

Manumbar

young 1867

Kabi?

Wife of Johnny Campbell (no. 40)

'Career of Campbell' MS, 6-7

1867 
42
Aboriginal name
Where contacted
Language group
Locality of origin
Other comments
Reference in published works

Date of contact

Purpose of published reference

43

Aboriginal name
Where contacted
Age
Language group
Other comments
Reference in published works
Date of contact
Purpose of published reference

44

Aboriginal name
European name
Where contacted
Language group
Locality of origin
Reference in notes, letters etc
Date of contact
Topics covered
Purpose of published reference

\section{European name}

Where contacted

Reference in notes, letters etc

Date of contact

Topics covered

46

\section{European name}

Reference in notes, letters etc
Waruin1, Waruindh2, Warun3, Waroon4

Manumbar

(mother) Kabi, (father) Wakka

Bunya Mountains

Nickname 'Monkey' or 'Wool' (3)

Friend of Turandiu (4)

TRTQ1, 74, 137

Curr2, 176

E $\mathcal{E} C 3,11$

'Career of Campbell' MS,4 7

ca. 1870

1 hair, "classes"

2 healing by crystal

3 woolly hair

\author{
Turandiu \\ Manumbar \\ youth \\ Kabi \\ -Bonda section \\ -friend of Warun (no. 42) \\ TRTQ, 137 \\ Curr, 178 \\ 'Career of Campbell' MS, 7 \\ $1860 \mathrm{~s}$ \\ 'classes' (TRTQ), Native Police story (Curr)
}

\section{Borin?}

Fred Ingham

Qld: Barambah

Kiramai

Herbert River, Queensland

MS 950 (F) (6)

8.10 .1924

words, sections

Kiramai Vocabulary

\section{Andrew Ball}

Queensland

MS 950 (F) (6)

1912

Section 'Bundie'

Kabu (Kabie?) Williams

MS950 (F) (6) 
Date of contact

Topics covered

\section{$47 \quad$ Aboriginal name}

\& Where contacted

$48 \quad$ Locality of origin

Reference in notes, letters etc

Date of contact

Topics covered

49

\section{Aboriginal name \\ European name \\ Language group \\ Locality of origin \\ Other comments}

Reference in published works

Reference in notes, letters etc

Date of contact

Topics covered

Purpose of published reference

50

Aboriginal name
European name
Where contacted

Age

Language group

Locality of origin

Other comments

Reference in published works

Reference in notes, letters etc

Date of contact

Topics covered

Purpose of published reference

51

\section{European name}

Where contacted

Age

Locality of origin

Reference in notes, letters etc

Date of contact

Topics covered

European name

Where contacted

Age

Other comments
1912 ?

-funerary practices

•words

-courting practices

'2 Natives'

Queensland-Barambah?

West of Burketown

MS950 (F) (6)

1912?

classes and totems

Wai

Maggie McLean

Wulili

born Taroom, Qld

Name means 'sideways'

AAAS, 1926

MS J.Y. Mathew collection, East Hawthorn,

Vic.)

1924 ?

Word list

Vocabulary

Barak ['a blackfellow']

William Barak

Coranderrk, Vic

181315.8.1903

Woiwurrung, Kulin

Yarra River

Related to Wonga (chief Yarra)

VHM (1911), 82

MS950 (F) (6); (E) (1)

1890 s

words, phratry names and hair

phratry names (curly and straight haired)

\section{Mrs Richards}

Coranderrk, Victoria

about 60 (1909)

Ballarat

MS950 (F) (1)

Jan. 1909

$\mathrm{E} \& \mathrm{C}$, sections and hair

James Cortwine (or Portwine)

Lake Condah, Victoria

nearly 80 y.o. (d. 1907)

Could be no. 51 
Reference in notes, letters etc

Date of contact

Topics covered

53

European name

Where contacted

Age

Reference in published works

Date of contact

Topics covered

Purpose of published reference

54

\section{European name}

Where contacted

Age

Reference in published works

Date of contact

Topics covered

Purpose of published reference

55

\section{European name}

Where contacted

Age

Reference in published works

Date of contact

Topics covered

Purpose of published reference

\section{European name}

Where contacted

Age

Reference in published works

Date of contact

Topics covered

Purpose of published reference

European name

Where contacted

Other comments

Reference in notes, letters etc

Date of contact

Topics covered

Purpose of published reference
MS950 (F) (9) Notebook

Aug. 1907

Distinguishing by hair Kurokaity and Kupaity moieties

unknown (1)

Lake Condah, Victoria

under 80 years

JRAI (1910), 166

1907, 1909

phratries

dark and light blood

unknown (2)

Lake Condah, Victoria

$60+$

JRAI (1910), 166

1907,1909

phratries

dark and light blood

unknown (3)

Lake Condah, Victoria

$60+$

JRAI (1910), 166

1907, 1909

phratries

dark and light blood

unknown (4)

Lake Condah, Victoria

$60+$

IRAI (1910), 166

1907, 1909

phratries

dark and light blood

Mary? Harry? Edwards

Lake Condah (?), Victoria

Could be 52,53 or 54

MS 950 (F) (9) Notebook

18 August 1909

Differences of hair between Kukokaity and

Kapaithy

moieties 
European name

Where contacted

Reference in notes, letters etc

Date of contact

Topics covered

59

European name

Where contacted

Reference in notes, letters etc

Date of contact

Topics covered

60

\begin{abstract}
Aboriginal name
European name

Where contacted

Age

Locality of origin

Other comments
\end{abstract}

Reference in notes, letters etc

Date of contact

Topics covered

61 European name

Where contacted

Age

Locality of origin

Other comments

Reference in published works

Reference in notes, letters etc

Date of contact

Topics covered

62
Aboriginal name
European name
Where contacted
Language group
Locality of origin
Reference in notes, letters etc
Date of contact
Topics covered

63
Ernest Mobourne

Lake Condah, Vic.

MS 950 (F) (9) Notebook

1907

- Name of Condah

-Sections

-Story of tortoise and snake

\section{Peter Ewart}

Lake Condah, Victoria

MS 950 (F) (9)

14-15/8/1907

2 Stories (discovery of fire and election(?) of a

King); Vocabulary

\section{Wirimanda}

Jackson Stewart

Lake Condah, Victoria

about 60 years

near Lake Boga

'half caste'

MS950 (F) (9)

$14 / 8 / 1907$

Sections; stories; initiation rites; words;

Supernatural beings

\author{
Isaac McDuff \\ Lake Condah, Victoria \\ elderly \\ Murray River, Swan Hill \\ - 6 feet 3 inches and 17 stone \\ - Married to Maria, Kabi woman (see no. 1) \\ JRAI (1910), 167 \\ $\mathrm{MS} 950$ (G) \\ 14/8/1907, 1909 \\ Crow story, phratry names and hair types
}

\author{
Monmoiko \\ Banjamin Manton \\ Ebenezer?/Lake Condah?, Victoria \\ Purabura \\ Swan Hill, Victoria \\ MS 950 (F) (1), Notebook \\ 1909 \\ hair types and sections
}

Ned McLennan

Ebenezer?/Lake Condah?, Victoria 
Age

Locality of origin

Reference in notes, letters etc

Date of contact

Topics covered

64

European name

Locality of origin

Reference in notes, letters etc

Date of contact

65

Aboriginal name

European name

Where contacted

Age

Locality of origin

Other comments

Reference in notes, letters etc

Date of contact

European name

Where contacted

Locality of origin

Reference in notes, letters etc

Date of contact

Topics covered

67 European name

Locality of origin

Date of contact

Topics covered

68

Aboriginal name

European name

Locality of origin

Topics covered

69

\section{Aboriginal name}

European name

Where contacted

Locality of origin

Other comments

Reference in published works

Date of contact

Topics covered

Purpose of published reference about 60

Pine Plains beyond Lake Albacutya (Wim-

mera), Victoria

MS 950 (F) (1)

1909

Sections/totems

Woodford Robinson

Loddon River, Vic.

MS 950 (F) (1) Notebook.

$1 / 2 / 1909$

Nganainganaitch

Anthony Anderson

Lake Condah?

70-80 y.o.

Richardson River (Bendigo-Murray)

-Plate presented by Duke of York (1901?)

-'King of Birchip'

MS590 (F) (1) Notebook.

1906? 1909?

Darby

Ramahyuck, Victoria (?)

Sale, Victoria

MS950 (F) (1) Notebook.

1906? 1909?

Points of Compass

Frank Blain

Allansford, Victoria

1906? 1909?

Sections/marriage rules

Nganainganaitch

Walter Johnson

Beaufort, Victoria

Section names

Bidhanin

King Billy

Ballarat, Victoria

b. Erchildoune, Victoria

5 feet 4 inches, very hairy indeed, 'jewish nose'

E E C, 75-6

RSNSW, 385

(probably not in person) $1880 \mathrm{~s}$

physical appearance

to establish 'Papuan' type 
70

European name

Where contacted

Reference in notes, letters etc

Date of contact

Topics covered

71

\section{Aboriginal name \\ Locality of origin \\ Other comments}

Reference in published works

Topics covered

72

\section{European name \\ Where contacted \\ Language group \\ Locality of origin}

Reference in notes, letters etc

Date of contact

Topics covered

Purpose of published reference

73

European name

Where contacted

Other comments

Reference in published works

Date of contact

Topics covered

Purpose of published reference

74

European name

Where contacted

Other comments

Reference in published works

Date of contact

Topics covered

European name

Where contacted

Age

Date of contact

Topics covered

\section{Old Kitty}

Lake Tyers, Victoria

MS 950 (Ab) (1); 'Gleanings in Aboriginal Gram-

marye' (typescript)

1891, June 1925

Unknown 1891; Language? 1925

unknown

Victoria

exceptionally intelligent

JRAI (1910), 167

phratry names

Harry Ord

Qld (Barambah?)

Gidabul?

Colinton, WashpooI, NSW

MS950 (F) (6) Notebook

1912? 1924?

-Sections

- Magic, dilly bags, clever man

-myths

-words?

Language etc.

Old Peter

Milroy station, Culgoa River, NSW

very hairy

$E \mathcal{E} C, 76$

RSNSW, 385

1880s

hair

establish physical types

\section{Teacup}

Between Bourke and Brewarrina, N.S.W.

children had straw-coloured hair and copper

skin

E \& C, 75

RSNSW, 384

$1880 \mathrm{~s}$

hair and skin colour

Jemmy Lounge

La Perouse, NSW

claimed to be 80

26 July 1895

Vocabulary 
76 European name

Language group

Locality of origin

Date of contact

Topics covered

$77 \quad$ Aboriginal name

European name

Where contacted

Age

Language group

Locality of origin

Other comments

Reference in notes, letters etc

Date of contact

Topics covered

\section{Mrs Doctor Dobbyn}

'Poolamacca' dialect

Broken Hill, NSW

1928 (second-hand, by mail)

Vocabulary

\section{Yungaipon}

David Unaipon

At home, Coburg, Victoria

42 at the time (1872-1967)

Ngarrinyeri

Mouth of Murray, Pt Macleay, S.A.

Inventor, Lay preacher, first published Aboriginal author

MS 950 (Aa) (3) (ii)

11-14 July 1914

Spiritual beliefs, E \& C myths, Relationships 